\title{
Nurses' level of Competence and Reported Practices Among Pediatric and Adult Ventilated Patients with COVID 19.
}

\author{
Mogedda Mohamed Mehany ${ }^{1}$, Eman Sayed Ahmed ${ }^{2} \&$ Amira Hassan Abdalfatah ${ }^{3}$. \\ 1. Assistant professor of Critical Care and Emergency Nursing, Faculty of Nursing, Assiut University, Egypt. \\ 2. Professor of Pediatric Nursing, Faculty of Nursing, Assiut University, Egypt. \\ ${ }^{3 .}$ Lecturer of Pediatric Nursing, Faculty of Nursing, Assiut University, Egypt.
}

\begin{abstract}
Critically care nurses must be competent in care of patients with COVID19 on mechanical ventilation which meets the specialized needs of the patient. Aim: To investigate nurses' level of competence and reported practices among ventilated adult and pediatric patients with COVID 19. Research Design: A descriptive research design was conducted in this study. Setting: The study was conducted in four intensive care units include general, trauma, critical care and pediatric intensive care unit. Subjects: Nurses who have a bachelor's degree of nursing sciences as a bedside nurse and dealing with patients connected to mechanical ventilation with COVID 19. Tools of data collection: Tool I: clinical scenario assessment tool. Tool two: nurses' reported practices (universal precautions) questionnaire. Results: The majority of nurses were incompetent in all breath types and lung pathological changes $(81.7 \%, 95 \%, 81.7 \% 95.0 \%)$ respectively, and majority of them had inappropriate reported practice according to policy of sharp equipment and environmental precaution Conclusion: It was found that more than half of studied nurses were incompetent and had inappropriate reported practice in dealing with ventilated patients with covid 19. Recommendation: Nurses' level of competence and practices among ventilated patients should be assessed at regular time
\end{abstract}

\section{Keywords: Adult and Pediatric Patients, Covid-19, Level of Competence, Mechanical Ventilation \& Reported Practices.}

\section{Introduction}

According to the World Health Organization (WHO), viral diseases continue to emerge and represent a serious issue to public health. Coronavirus disease2019 (COVID-19), which started in Hunan seafood market at Wuhan, South China in December 2019 and has been declared a worldwide pandemic on March 11,2020 , is a novel infectious disease that causes respiratory illness and death. Coronaviruses are a large family of viruses which may cause disease in animals or humans. They usually cause a respiratory infection ranging from the common cold to more severe diseases (Beeching, 2020).

COVID-19 affected adult as well as children in which Pediatric COVID-19 accounts for a small percentage of patients with outbreaks and is often milder than adults but can progress to severe disease in some cases. Even neonates can suffer from COVID-19. Children may play a role as a spreader in the community (choi et al., 2020). Time from exposure and symptom onset is generally between two and 14 days, with an average of five days. Common symptoms include fever, cough, sneezing and shortness of breath (Beeching, 2020).

Complications may include pneumonia, throat pain and acute respiratory distress syndrome. Currently, there is no specific antiviral treatment; efforts consist of symptom abolition supportive therapy.
Recommended preventive measures include washing hands with soap, covering the mouth when coughing, maintaining 1-meter distance from other people and monitoring and self-isolation for fourteen days for people who suspect they are infected (Palmore, 2020).

The progression of the disease leads to worsening of the symptoms and at this point the patient is shifted to ICU. In emergency conditions, non-invasive or invasive mechanical ventilation should be provided to the patient (Cascella, 2020).

Mechanical ventilation (MV) has a key role in managing COVID-19-associated respiratory failure. The recovery of patients in intensive care units (ICUs) depends on mechanical ventilation. Most pediatric and adult critically ill patients admitted to ICU because of lung pathology and its consequent needs for mechanical ventilation. (Botha, 2013).

In spite of potential life-threatening complications, mechanical ventilation remains the most common therapeutic modality undertaken in intensive care units. Special precautions are necessary during intubation. The procedure should be executed by an expert operator who uses personal protective equipment (PPE) such as FFP3 or N95 mask, protective goggles, disposable gown long sleeve raincoat, disposable double socks, and gloves (Palmore, 2020). 
Thus the nurse who gives nursing care to ventilated patients in ICU must be competent in knowledge and have high quality practice level tailored to the needs of these patients. (Marshall et al., 2017).

Tailored specific knowledge of mechanical ventilation refers to mastering information base, complex decision-making skills and high quality technological care. The nurse should update her knowledge regarding modern ventilator innovations and be trained on application of different strategies and settings in patients with different lung diseases requiring mechanical ventilation. (Suhara et al., 2013).

The nurse should be alert in identifying complications of ventilated patients to prevent further lung injury as ventilator associated pneumonia (VAP) and pneumothorax. This preventive role of the nurse will decrease length of hospital stay, decrease medical cost and lead to better patient prognosis.

(Botha, 2013).

\section{Significance of the study}

The COVID-19 pandemic in Egypt is part of the worldwide pandemic of coronavirus disease 2019 (COVID-19) caused by severe acute respiratory syndrome coronavirus 2 (SARS-CoV-2). The virus was confirmed to have reached Egypt on 14 February 2020. Egypt's health ministry announced the first case in the country at Cairo International Airport involving a Chinese nationality on 14 February. Egyptian authorities had notified the World Health Organization (WHO) and the patient had been placed in quarantined isolation in hospital. On June 19, 2020, the highest daily increase in cases was recorded at 1,774. As of August 27, 2020, the daily number of coronavirus cases (COVID-19) in Egypt reached its highest at 98,062 cases. As of the same date, there were 5,342 deaths and 69,612 recoveries recorded in the country. (Egypt's health ministry, 2020). The nurse who cares for the mechanically ventilated patient with COVID19 must demonstrate competence in order to be able to recognize adverse events which may occur.

\section{Research questions}

1. Are the nurses competent when caring with ventilated patients with COVID 19.

2. Did the nurses have appropriate practices about universal precautions when dealing with ventilated patients with COVID 19

\section{Subjects \& Method}

\section{Aims of the study}

To investigate nurses' level of competence and reported practices among pediatric and adult ventilated patients with COVID 19.

\section{Research design \\ Descriptive research design was used in this study. Setting}

The study was conducted at four ICU, three of them (general, trauma, and critical care) anesthesia intensive care units in main Assiut university hospital, and pediatric intensive care unit in Assiut university children hospital

Subjects:-

The study subjects include non-probability purposive sample of professional nurses either male or female and their ages ranged from 22- 30 years who were 60 nurses.

\section{Inclusion criteria}

1. Nurses who have a bachelor's degree of nursing sciences

2. Nurses who have one-year experience as a bedside nurse and dealing with patients connected to mechanical ventilation with and without COVID 19.

3. Their age ranged from $22-30$ years old as the professional nurses once aged 30 years, usually have administrative work.

\section{Tools of the study}

Two tools were used in this study: The two tools were developed by the researchers based on an extensive literature review (Veloski et al., 2005), (Botha, 2013), (Labrague et al., 2012) \& (Shauq et al., 2014).

Tool I: clinical scenario assessment tool: It includes four clinical scenarios; two for ventilated adult and child patients with no lung pathology it covers basic knowledge of mechanical ventilation as breath type, mode, setting and arterial blood gases (ABG). It consists of ten MCQ's questions (N-10) and two another clinical scenario for ventilated adult and child patients with decreased lung compliance (acute respiratory distress syndrome) consists of six $(\mathrm{N}=6)$ MCQ's. The patient with ARDS requires low tidal volumes, (4-8mls/kg/IDBW) airway pressures under $35 \mathrm{~cm} / \mathrm{H} 2 \mathrm{O}$, high PEEP $(14-18 \mathrm{~cm} / \mathrm{H} 2 \mathrm{O})$ and high mandatory respiratory rates $(>20 \mathrm{bpm})$.

These four-scenarios aimed to measure nurses' competencies related to dealing with adult and child patients on mechanical ventilation with COVID 19. It was necessary to develop the clinical scenarios in terms of two different lung conditions, as the strategies, ventilator settings, nursing care and nursing interventions differ for each of the lung conditions previously alluded to." It is no longer acceptable to apply a single strategy of ventilation for all (such) patients. This is especially true with increasing awareness of the complications of mechanical ventilation such as barotraumas, polytrauma, and biotrauma. 
Tool Two: Nurses' reported practices (universal precautions) questionnaire sheet that was developed by the researchers. It aimed to measure nurses' practice level regarding universal precautions when dealing with child and adult patients with Covid19. It includes questions related to the following items as Self-protection precautions, Environmental precautions and Policy and sharp equipment precautions every question was answered by yes or no.

\section{Scoring system}

\section{Knowledge scoring system}

Each question was scored as (1) for a correct answer and (zero) for an incorrect answer. The total knowledge score was calculated as incompetent if the percent score was less than $75 \%$ and was considered competent if percent was $75 \%$ and more.

\section{Practice scoring system}

Each question was scored as (1) for a correct action and (zero) for an incorrect action. While the total practice score was calculated as inappropriate practices if the percent score was less than $75 \%$ and was considered appropriate practices if percent was $75 \%$ and more.

\section{Methods}

The two tools were developed by the researchers based on an extensive up-to-date literature review (Veloski et al., 2005), (Botha, 2013), (Labrague et al., 2012) \& (Shauq et al., 2014).

- Pilot Study was carried out on $10 \%$ of nurses to test the clarity and applicability of the tool. Based on the results of pilot study, there were no modification in the tools

- Internal consistency of reliability was measured using alpha Cronbach test and $\mathrm{R}$ was 0.86 and 0.82 for tool 1and tool II, respectively.

- Content validity: The developed tools were tested for the content validity by selected juries of critical care medical and nursing professionals to assess the clarity, feasibility, and applicability of the tools. Content validity index (CVI) was $87 \%$, and $85 \%$ for tool 1 and tool II, respectively.

- Official permission was obtained from the head of Assiut university hospital and children university hospital to collect data from the four units in Assiut university hospital and children university hospital and the permission was sent to these units. Written informed consent from studied nurses was obtained. Research proposal was approved from Ethical Committee in the Faculty of Nursing. There was no risk for study subjects during application of the research. The study followed common ethical principles in clinical research. Confidentiality and anonymity were assured. Study subjects had the right to refuse to participate or withdraw from the study without any rational any time. Study subjects' privacy was considered during collection of data.

- First: the researcher began to collect data from April 2020 to September 2020 from (60) nurses who accepted to participate in this study from the four units. The researchers contact with the nurses during and after data collection period via WhatsApp due to the spread of world the epidemic Corona virus during this period, restriction of ICU on decreasing number of personal as possible.

\section{Statistical analysis}

The collected data were organized, categorized, coded, tabulated, and analyzed using the Statistical Package for social sciences (SPSS) version 18. Data were presented using numbers, percentages, means, and standard deviation. 


\section{Results}

Table (1): Distribution of studied nurses according to their characteristics.

\begin{tabular}{|c|c|c|}
\hline Nurses' characteristics & No. (60) & $\%$ \\
\hline \multicolumn{3}{|l|}{ Age: (years) } \\
\hline $\begin{array}{l}<25 \\
\geq 25\end{array}$ & $\begin{array}{l}14 \\
46\end{array}$ & $\begin{array}{l}23.3 \\
76.7\end{array}$ \\
\hline Mean \pm SD & \multicolumn{2}{|c|}{$26.4 \pm 3.32$} \\
\hline \multicolumn{3}{|l|}{ Type of ICU: } \\
\hline Pediatric ICU & 12 & 20.0 \\
\hline General ICU & 24 & 40.0 \\
\hline Emergency ICU & 12 & 20.0 \\
\hline Trauma ICU & 12 & 20.0 \\
\hline \multicolumn{3}{|l|}{ Years of experience } \\
\hline Less than 2 years & 11 & 18.3 \\
\hline From $2-5$ years & 36 & 60.0 \\
\hline More than 5 years & 13 & 21.7 \\
\hline Mean \pm SD & \multicolumn{2}{|c|}{$4.1 \pm 3.38$} \\
\hline Previous working in other place & & \\
\hline Yes & 7 & 11.7 \\
\hline No & 53 & 88.3 \\
\hline Attendance of previous training on mechanical ventilation & & \\
\hline Yes & 34 & 56.7 \\
\hline No & 26 & 43.3 \\
\hline
\end{tabular}

Table (2): Percentage distribution of studied nurses' competence regarding modes, parameters and weaning among ventilated patients with COVID 19.

\begin{tabular}{|c|c|c|}
\hline Basic knowledge of mechanical ventilation & No. (60) & $\%$ \\
\hline $\begin{array}{l}\text { I- Indications of mechanical ventilation } \\
\text { Competent } \\
\text { Incompetent }\end{array}$ & $\begin{array}{l}50 \\
10\end{array}$ & $\begin{array}{l}83.3 \\
16.7\end{array}$ \\
\hline $\begin{array}{l}\text { II- Modes of } \\
\text { - SIMV mode of mechanical ventilation } \\
\text { Competent } \\
\text { Incompetent }\end{array}$ & $\begin{array}{l}38 \\
22\end{array}$ & $\begin{array}{l}63.4 \\
36.6\end{array}$ \\
\hline - Pressure Support Ventilation (PSV): & & \\
\hline $\begin{array}{l}\text { Competent } \\
\text { Incompetent }\end{array}$ & $\begin{array}{l}18 \\
42\end{array}$ & $\begin{array}{l}30.0 \\
70.0\end{array}$ \\
\hline $\begin{array}{l}\text { III- Diagnostic tests that best reflect oxygenation and } \\
\text { ventilation: }\end{array}$ & & \\
\hline $\begin{array}{l}\text { Competent } \\
\text { Incompetent }\end{array}$ & $\begin{array}{l}12 \\
48\end{array}$ & $\begin{array}{l}20.0 \\
80.0\end{array}$ \\
\hline $\begin{array}{l}\text { IV- Parameters of MV } \\
\text { Competent } \\
\text { Incompetent }\end{array}$ & $\begin{array}{l}26 \\
34\end{array}$ & $\begin{array}{l}43.4 \\
56.6\end{array}$ \\
\hline $\begin{array}{l}\text { Trigger sensitivity } \\
\text { Competent } \\
\text { Incompetent } \\
\end{array}$ & $\begin{array}{l}20 \\
40\end{array}$ & $\begin{array}{l}33.3 \\
66.7\end{array}$ \\
\hline $\begin{array}{l}\text { V- Weaning } \\
\text { - Indications of weaning: } \\
\text { Competent } \\
\text { Incompetent }\end{array}$ & $\begin{array}{c}6 \\
54\end{array}$ & $\begin{array}{l}10.0 \\
90.0\end{array}$ \\
\hline $\begin{array}{l}\text { - Sequence of weaning } \\
\text { Competent } \\
\text { Incompetent }\end{array}$ & $\begin{array}{l}20 \\
40\end{array}$ & $\begin{array}{l}33.3 \\
66.7\end{array}$ \\
\hline $\begin{array}{l}\text { Extubating a patient } \\
\text { Competent } \\
\text { Incompetent }\end{array}$ & $\begin{array}{l}39 \\
21\end{array}$ & $\begin{array}{l}65.0 \\
35.0\end{array}$ \\
\hline
\end{tabular}


Table (3): Percentage distribution of studied nurses' competence regarding breath types among ventilated patients with COVID 19.

\begin{tabular}{|c|c|c|c|c|}
\hline Breath types & & & No. (60) & $\%$ \\
\hline \multirow[t]{6}{*}{ Spontaneous } & Volume & $\begin{array}{l}\text { Competent } \\
\text { Incompetent }\end{array}$ & $\begin{array}{l}14 \\
46\end{array}$ & $\begin{array}{l}23.3 \\
76.7\end{array}$ \\
\hline & Pressure & $\begin{array}{l}\text { Competent } \\
\text { Incompetent }\end{array}$ & $\begin{array}{l}11 \\
49\end{array}$ & $\begin{array}{l}18.3 \\
81.7\end{array}$ \\
\hline & Flow & Competent & 14 & 23.3 \\
\hline & & Incompetent & 46 & 76.7 \\
\hline & Time & Competent & 14 & 23.3 \\
\hline & & Incompetent & 46 & 76.7 \\
\hline \multirow[t]{4}{*}{ Volume Control } & Volume & $\begin{array}{l}\text { Competent } \\
\text { Incompetent }\end{array}$ & $\begin{array}{l}18 \\
42\end{array}$ & $\begin{array}{l}30.0 \\
70.0\end{array}$ \\
\hline & Pressure & $\begin{array}{l}\text { Competent } \\
\text { Incompetent }\end{array}$ & $\begin{array}{l}14 \\
46\end{array}$ & $\begin{array}{l}23.3 \\
76.7\end{array}$ \\
\hline & Flow & $\begin{array}{l}\text { Competent } \\
\text { Incompetent }\end{array}$ & $\begin{array}{c}8 \\
52\end{array}$ & $\begin{array}{l}13.3 \\
86.7\end{array}$ \\
\hline & Time & $\begin{array}{l}\text { Competent } \\
\text { Incompetent }\end{array}$ & $\begin{array}{l}14 \\
46\end{array}$ & $\begin{array}{l}23.3 \\
76.7\end{array}$ \\
\hline \multirow[t]{4}{*}{ Pressure Control } & Volume & $\begin{array}{l}\text { Competent } \\
\text { Incompetent }\end{array}$ & $\begin{array}{l}14 \\
46\end{array}$ & $\begin{array}{l}23.3 \\
76.7\end{array}$ \\
\hline & Pressure & $\begin{array}{l}\text { Competent } \\
\text { Incompetent }\end{array}$ & $\begin{array}{c}11 \\
3 \\
46\end{array}$ & $\begin{array}{c}18.3 \\
5.0 \\
76.7\end{array}$ \\
\hline & Flow & $\begin{array}{l}\text { Competent } \\
\text { Incompetent }\end{array}$ & $\begin{array}{l}14 \\
46 \\
\end{array}$ & $\begin{array}{l}23.3 \\
76.7\end{array}$ \\
\hline & Time & $\begin{array}{l}\text { Competent } \\
\text { Incompetent }\end{array}$ & $\begin{array}{c}3 \\
57\end{array}$ & $\begin{array}{l}5.0 \\
95\end{array}$ \\
\hline \multirow[t]{4}{*}{ Pressure Support } & Volume & $\begin{array}{l}\text { Competent } \\
\text { Incompetent }\end{array}$ & $\begin{array}{l}14 \\
46\end{array}$ & $\begin{array}{l}23.3 \\
76.7\end{array}$ \\
\hline & Pressure & $\begin{array}{l}\text { Competent } \\
\text { Incompetent }\end{array}$ & $\begin{array}{l}11 \\
49\end{array}$ & $\begin{array}{l}18.3 \\
81.7\end{array}$ \\
\hline & Flow & $\begin{array}{l}\text { Competent } \\
\text { Incompetent }\end{array}$ & $\begin{array}{l}14 \\
46\end{array}$ & $\begin{array}{l}23.3 \\
76.7\end{array}$ \\
\hline & Time & $\begin{array}{l}\text { Competent } \\
\text { Incompetent }\end{array}$ & $\begin{array}{l}14 \\
46\end{array}$ & $\begin{array}{l}23.3 \\
76.7\end{array}$ \\
\hline
\end{tabular}

Table (4): percentage distribution of studied nurses' competence regarding specific knowledge among ventilated patients with COVID 19 related lung pathology (ARDS)

\begin{tabular}{|l|c|c|}
\hline \multicolumn{1}{|c|}{ Items lung pathology (ARDS ) } & No. (60) & \% \\
\hline Lung pathological changes caused by COVID 19 & 3 & 5.0 \\
Competent & 57 & 95.0 \\
Incompetent & & \\
\hline Most appropriate choices of ventilator settings based on correct & 18 & 30.0 \\
interpretation of ABG & 42 & 70.0 \\
Competent & & \\
Incompetent & 15 & 25.0 \\
\hline Most appropriate intervention at this stage: & 45 & 75.0 \\
\hline Competent & & \\
Incompetent & 40 & 66.7 \\
\hline Role of PEEP at alveolar level of the lungs: & 20 & 33.3 \\
\hline Competent & & \\
Incompetent & & \\
\hline
\end{tabular}


Table (5): percentage distribution of studied nurses' competence regarding their interpretation of patient's ABG.

\begin{tabular}{|l|c|c|}
\hline \multicolumn{1}{|c|}{ Patient's ABG } & No. (60) & \% \\
\hline PH & & \\
Competent & 51 & 85.0 \\
Incompetent & 9 & 15.0 \\
\hline PaCO & & \\
Competent & 47 & 78.3 \\
Incompetent & 13 & 21.7 \\
\hline PaO $_{2}$ & & \\
\hline Competent & 36 & 60.0 \\
Incompetent & 24 & 40.0 \\
\hline BE & & \\
\hline Competent & 26 & 43.4 \\
Incompetent & 34 & 56.6 \\
\hline HCO & & \\
Competent & 35 & 58.3 \\
Incompetent & 25 & 41.7 \\
\hline
\end{tabular}

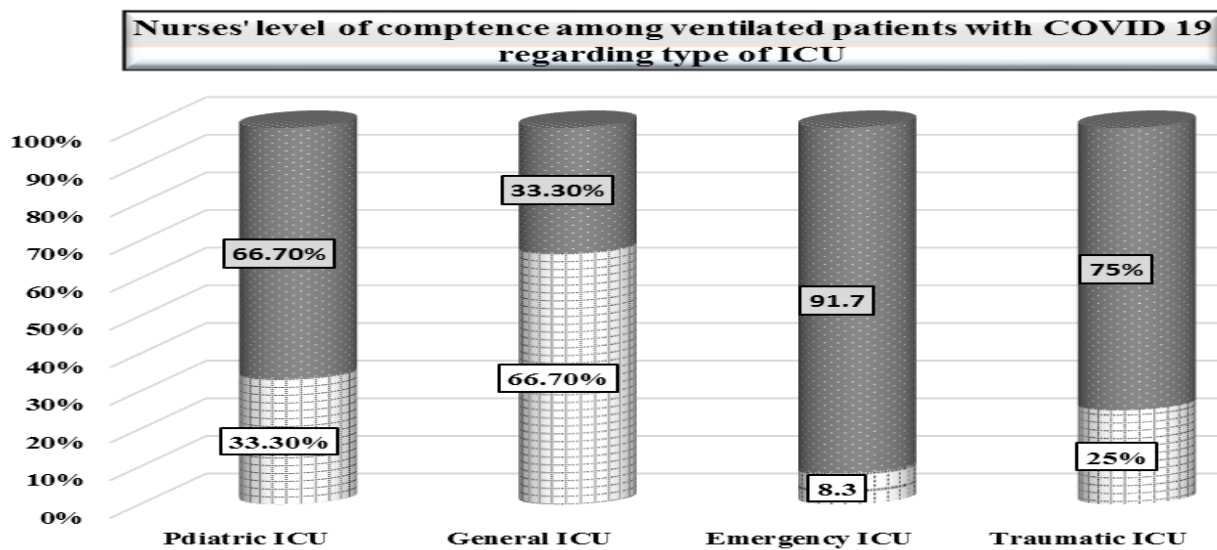

WComptent $\square$ Incomptent

Figure (1): nurses' level of competence among ventilated patients with covid19 regarding type of ICU.

Table (6): reported nurses' appropriate practices about universal precautions when dealing with ventilated patients with COVID 19.

\begin{tabular}{|l|c|c|}
\hline \multicolumn{1}{|c|}{ Universal precautions } & No. $(\mathbf{6 0})$ & \% \\
\hline Self-protection precautions & & \\
\hline Hand washing & 57 & 95.0 \\
\hline Wearing gloves & 56 & 93.3 \\
\hline Wearing an appropriate protective mask (N95) properly & 39 & 65.0 \\
\hline Wearing eye goggles & 54 & 90.0 \\
& 6 & 10.0 \\
\hline Cleaning hands after contact with respiratory secretions & 58 & 96.7 \\
\hline Wearing shoe covers in the ICU & 38 & 63.3 \\
\hline Environmental precautions & & \\
\hline Disinfecting frequently touched objects and surfaces & 53 & 88.3 \\
\hline Remove personal protective equipment appropriately after leaving ICU & 59 & 98.3 \\
\hline
\end{tabular}




\begin{tabular}{|l|c|c|}
\hline $\begin{array}{l}\text { Single-use tools are used, whenever possible, cleaning and disinfection of shared } \\
\text { tools with ethyl alcohol at 70\% concentration upon completion of each patient. }\end{array}$ & 47 & 78.3 \\
\hline Safe waste disposal, environmental cleaning, and sterilization of patient equipment & 55 & 91.7 \\
\hline $\begin{array}{l}\text { Each patient was placed in one well-ventilated room with a closed door and a } \\
\text { dedicated bathroom }\end{array}$ & 21 & 35.0 \\
\hline Policy and sharp equipment precautions & & \\
\hline Adhering to standards for infection prevention and control. & 37 & 61.7 \\
\hline Appropriate disposal of sharp equipment & 51 & 85.0 \\
\hline $\begin{array}{l}\text { Continuous evaluation of the cleaning, sterilization and disinfection operations and } \\
\text { their periodicity }\end{array}$ & 43 & 71.7 \\
\hline A mobile device is designated for x-ray imaging purposes & 38 & 63.3 \\
\hline $\begin{array}{l}\text { A commitment to limit the transfer of a patient suspected of having a COVID-19 } \\
\text { infection between departments unless necessary }\end{array}$ & 27 & 45.0 \\
\hline
\end{tabular}

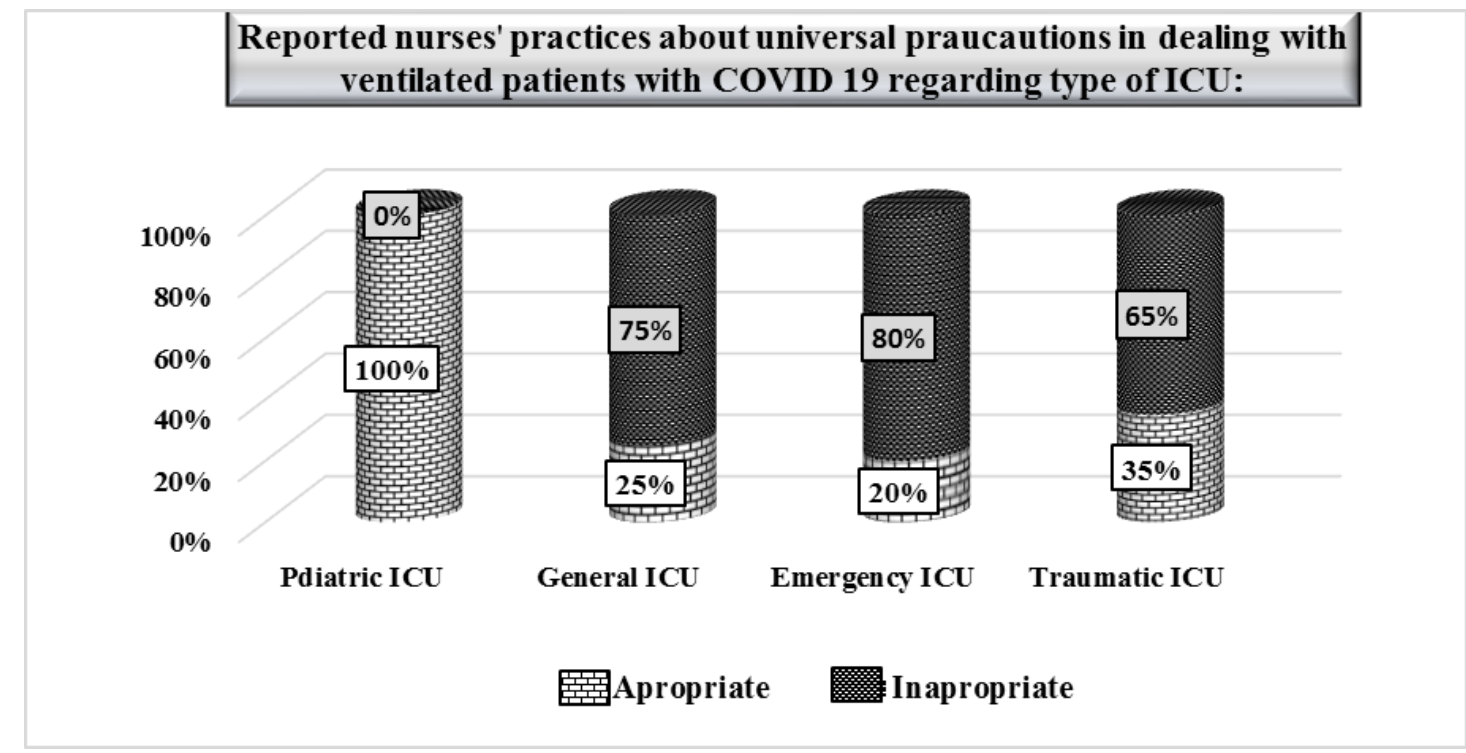

Figure (2): Nurses' level of competence $\&$ reported nurses' practices about universal precautions dealing with ventilated patients with COVID 19.

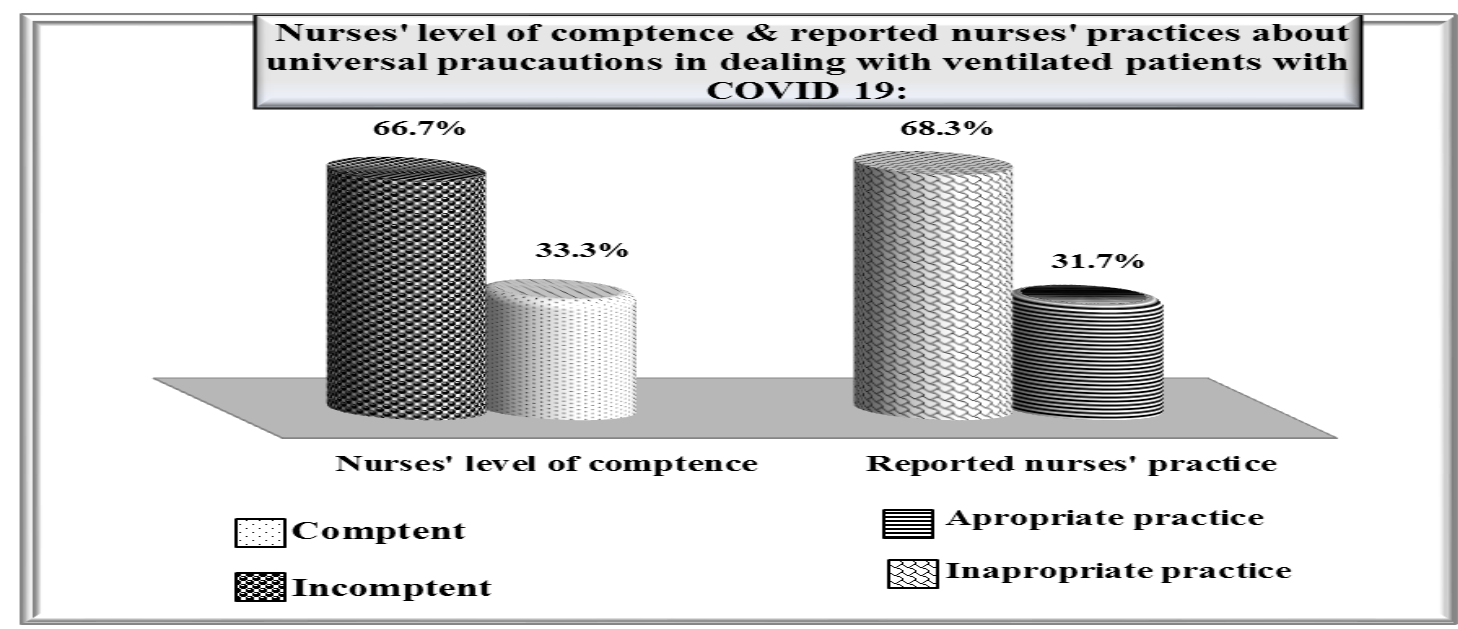

Figure (3): Nurses' level of competence \& reported nurses' practices about universal precautions dealing with ventilated patients with COVID 19. 
Table (1): Illustrates distribution of studied nurses according to their characteristics. It was noticed that more than three quarters of nurses $(76.7 \%)$ their age $\geq 25$ years old. According to type of ICU, more than one quarter of nurses worked in general ICU (40.0\%). As regarding years of experience, more than half of studied nurses $(60.0 \%)$ had 2-5 years of experience. According to previous working state, the majority of studied nurses did not work in any place previously. It was found that more than half $(56.7 \%)$ of studied nurses attended previous training on MV.

Table (2): Percentage distribution of studied nurses' competence regarding modes, parameters and weaning among ventilated patients with Covid19. It was noticed that more than half of studied nurses were competent as regarding indication, extubated patient, and mode of MV (83.3,63.4,65.0\% respectively). It was found that more than half of the studied nurses were incompetent as regarding PSV, diagnostic test, parameters of MV, trigger sensitivity, indication of weaning and sequence of weaning $(70.0 \%, 80.0 \%, 56.6 \%, 66.7 \%, 90.0 \%, 66.7 \%)$, respectively.

Table (3): Shows percentage distribution of studied nurses' competence regarding breath types among ventilated patients with covid19. It was found that in all breath types, most of nurses were incompetent $(81.7 \%, 95 \%, 81.7 \%)$ respectively.

Table (4): Illustrates percentage distribution of studied nurses' competence regarding specific knowledge among ventilated patients with covid19 related lung pathology (ARDS). It was noticed that most of the studied nurses $(95.0 \%)$ were incompetent according to lung pathological changes and more than three quarters of them were incompetent in ventilator setting and appropriate intervention $(70.0 \%$, and $75.0 \%)$, respectively while more than half of them were competent in role of PEEP $(66.7 \%)$.

Table (5): Shows percentage distribution of studied nurses' competence regarding their interpretation of patient's ABG. It was found that most of the studied nurses were competent in $\mathrm{PH}$ interpretation (85.0\%) and more than half of them were competent in interpretations of $\mathrm{Paco}_{2}, \mathrm{PaO}_{2}, \mathrm{SBC}(78.3 \%, 60.0 \%$, $58.3 \%)$, respectively while more than one third of them were competent in BE+ 4(43.4).

Figure (1): This figure illustrates nurses' level of competence among ventilated patients with covid19 regarding type of ICU. It was found that more than half of the studied nurses in general ICU (66.70\%) were competent while the majority of nurses in emergency ICU were incompetent $(91.7 \%)$

Table (6): Indicates reported nurses appropriate practices about universal precautions when dealing with ventilated patients with covid19. It was noticed that the majority of nurses had appropriate reported practice specially in self-protection precaution (95.0\%, 93.3\%, 90.0\%, 96.7\%), respectively. According to environmental precaution, the majority of the studied nurses had inappropriate reported practice $(88.3 \%, 98.3 \%, 91.7 \%)$, respectively and the majority of them $(85.0 \%)$ had inappropriate reported practice according to policy and sharp equipment.

Figure (2): This figure shows reported practices about universal precautions in dealing with ventilated patients with covid19 regarding type of ICU. It was noticed that all studied nurses in pediatric ICU had appropriate practice $(100 \%)$ while more than half of studied nurses in other ICUs had inappropriate reported practice $(75 \%, 80 \%$, and $65 \%)$, respectively.

Figure (3): This figure indicates nurses' level of competence and reported practice about universal precautions in dealing with ventilated patients with covid19. It was found that more than half of studied nurses were incompetent and had inappropriate reported practice $(66.7 \%$, and $68.3 \%)$ respectively in dealing with ventilated patients with covid19.

\section{Discussion}

Caring of adult patients and children on mechanical ventilation in adult and pediatric ICUs is demanding and complex (Blackwood $\boldsymbol{e t} \boldsymbol{a l}$., 2013). It is essential to have knowledgeable and skilled nurses to care for the mechanical ventilated comprehensive care and recognizing their knowledge and skill has great value before assigning them for such care (Grossbach et al., 2011).

The result of the present study showed that more than half of studied nurses were competent as regarding indication, extubated patient and mode of MV, this result may be due to basic principles of (MV) trained and educated well during period of undergraduate and apply it well in clinical field. This agree with (Grossbach et al., 2011) who stated that nurses need to be equipped with basic knowledge on ventilator settings, with expertise in invasive monitoring and must be highly competent in assessing patient safety and preventing complications.

This also agree with (Lakanmaa et al., 2015) who stated that nurses self-rated their professional competence (related to the profession in general) as good. Although more than half of studied nurses attended previous training on $\mathrm{MV}$, the current study presented that more than two thirds of the studied nurses were incompetent as regarding PSV, diagnostic test, parameters of MV, trigger sensitivity, indication of weaning and sequence of weaning, this may be due to lack of on job continuous training in their clinical field. 
Another cause of nurse's lack the efficiency of updating their practice after being in the clinical field for long time and possible explanation for this finding could be the workload. This result is agreed with (Blackwood et al., 2013) who revealed that nurses had minimal knowledge about settings such as respiratory rate, inspiratory pressure, and pressure support.

The present study revealed that the majority of nurses were incompetent in all of breath types (volume, pressure, flow, and time) this may be attributed to this specific detail of MV is the responsibility of the doctor in Assiut university intensive care unit. This finding is agreed with those of (Istomina et al., 2011) who reported that the majority of nurses frequently were incompetent in their clinical practice. This may be interpreted as nurses had incomplete information as regarding breath types due to lack of training courses.

The results in the present study showed that more than two thirds of studied nurses were incompetent in ventilator setting and appropriate intervention, this agree with Botha, (2013) who showed that a poor level of competence $(<50 \%)$ amongst nurses both ICU qualified and non-ICU qualified with regard to mechanical ventilation.

The current study revealed that the majority of the studied nurses were competent in $\mathrm{PH}$ interpretation and more than half of them were competent in Paco2, $\mathrm{Pao} 2$, and Hco3, this can be interpreted as nurses had adequate knowledge regarding $\mathrm{ABG}$ interpretation due to adequately handled during their study in the undergraduate period, and due to their years of experience in working in ICU .

According to nurses' level of competence among ventilated patients with covid19 regarding type of ICU, it was found that more than half of the studied nurses in general ICU were competent while the majority of nurses in emergency ICU were incompetent, this can be interpreted as nurses in general ICU had more experience and had facilities in performing care of mechanical ventilated patient than those in emergency ICU. In addition to general ICU is the oldest ICU in Assiut university hospital and all types of critical ill patients were admitted to it.

The present study revealed that the majority of nurses had appropriate reported practices especially in selfprotection precaution. This may be attributed to social media covered these self-protection precautions very well during period of COVID 19. This agree with Shauq et al., (2014) who stated that most of the participants had acceptable level of knowledge regarding universal precautions this also agree with Labrague et al., (2012) who stated that nurses have a high compliance of standard precautions

The results of the present study showed that all studied nurses in pediatric ICU had appropriate reported practice while more than half of studied nurses in other ICUs had inappropriate reported practice, this can be interpreted as administrator of pediatric ICU focuses on applying universal precautions, because children have lower immunity than those of adults. So, he obligates and encourage pediatric ICU nurses to review literatures and attending training courses related to infection control than those in others ICU hospital. This disagree with Shauq et al., (2014) who stated that all participants had accepted level of knowledge regarding all aspects of universal precautions.

Finally, the current study showed that more than half of studied nurses were incompetent and had inappropriate practices about universal precautions in dealing with ventilated patients with covid19. There is an urgent attention is needed to promote the role of a nurse to be competent by special training. Nurse in these areas must be encouraged to attend related seminars and workshops related to care of patients connected to MV. This study result contributed to the overall needs for improving the nursing care for the mechanically ventilated patients (Faidy et al., 2014).

\section{Conclusion}

Based on the findings of the current study, it can be concluded that more than half of studied nurses were incompetent and had inappropriate reported practices in dealing with ventilated patients with covid19.

\section{Recommendations}

- Orientation program should be utilized for newly graduated nurses who are working in critical care units.

- Nurses' level of competence and practices among ventilated patients should be assessed at regular time by the trainer who are responsible for annual training program.

- Periodic refreshing courses about mechanical ventilation for these nurses especially in the area of breath types, pressure support ventilation (PSV) and lung pathological changes according to competence base.

- Nurses should add to their routine duties the regular reading to update their performance. They should always be encouraged to attend scientific meeting and conferences to keep pace with the rapid growing plenty of knowledge and practice necessary to improve nursing care offered and patients outcomes. 


\section{References:}

- Ahmad S., (2020): A Review of COVID-19 (Coronavirus Disease-2019) Diagnosis, Treatments and Prevention. Eurasian Journal of Medicine and Oncology, 4(2), 116-125. https://doi.org/10.14744/ejmo.2020.90853.

- Beeching N., Fletcher T., \& Fowler R., (2020): Coronavirus disease 2019 (COVID-19) Symptoms, diagnosis and treatment | BMJ Best Practice. In BMJ Group (pp. 1-53). https://bestpractice.bmj.com/topics/en-gb/3000168.

- Blackwood, B., Junk, C., Lyons, J., McAuley, D., \& Rose, L., (2013): Role responsibilities in mechanical ventilation and weaning in pediatric intensive care units: a national survey. American Journal of Critical Care, 22(3), 189-197.

- Botha, M., (2013): Level of nurses' competence in mechanical ventilation in intensive care units of two tertiary health care institutions in Gauteng (Doctoral dissertation).Retrieved from https://core.ac.uk/download/pdf/39671846.pdf

- Cascella M., Rajnik M., Cuomo A., Dulebohn S., \& Di Napoli R., (2020): Features, Evaluation and Treatment Coronavirus (COVID-19) - StatPearls NCBI Bookshelf. In StatPearls (pp. 1-17). https://www.ncbi.nlm.nih.gov/pubmed/32150360.

- Choi, S., Kim, H., Kang, J., Kim, D., \& Cho, E., (2020): Epidemiology and clinical features of coronavirus disease 2019 in children. Clinical and experimental pediatrics, 63(4), 125.

- Egypt's health ministry announces first confirmed coronavirus case". France 24. 14 February (2020): Archived from the original on 16 February 2020. Retrieved 16 February 2020.

- Faidy, A., Ouesph, B., Yutuc, N., Melki, S., Tamonan, E., Jamaly, A., \& Mohidin, S., (2014): Care of Mechanical Ventilated Patients in General Ward: Nurses Perspective. GSTF Journal of Nursing and Health Care, 1(2), 1-5. https://doi.org/10.5176/2345-718x_1.2.27.

- Grossbach, I., Chlan, L., \& Tracy, M., (2011): Overview of mechanical ventilatory support and management of patient-and ventilator-related responses. Critical care nurse, 31(3), 30-44.

- Istomina, N., Suominen, T., Razbadauskas, A., Martinkėnas, A., Meretoja, R., \& Leino-Kilpi, H., (2011): Competence of nurses and factors associated with it. Medicina, 47(4), 33.

- Labrague, L., Rosales, R., \& Tizon, M., (2012): Knowledge of and compliance with standard precautions among student nurses. International journal of advanced nursing studies, 1(2), 84-97.

- Lakanmaa, R., Suominen, T., Ritmala-Castrén, M., Vahlberg, T., \& Leino-Kilpi, H., (2015): Basic Competence of Intensive Care Unit Nurses:
Cross-Sectional Survey Study. BioMed Research International, 2015, 1-13. https://doi.org/10.1155/2015/536724.

- Marshall, J., Bosco, L., Adhikari, N., Connolly, B., Diaz, J., Dorman, T., Fowler, R., Meyfroidt, G., Nakagawa, S., Pelosi, P., Vincent, J., Vollman, K., \& Zimmerman, J., (2017): What is an intensive care unit? A report of the task force of the World Federation of Societies of Intensive and Critical Care Medicine. Journal of Critical Care, 37, 270-276. https://doi.org/10.1016/j.jcrc.2016.07.015.

- Palmore, T., \& Bloom, A., (2020): Coronavirus disease 2019 (COVID-19): Infection control in health care and home settings. Retrieved from UpToDate website: https://www.uptodate.com/contents/coronavirusdisease-2019-covid-19-infection-control-in-healthcare-and-home-settings.

- Shauq, A., Obaid, K., Zaid, W., Summer, K., Ulaa, N., Sabeh, O., \& Amna, M., (2014): Nurses Knowledge about Universal Precautions in Neonatal Intensive Care Unit at Pediatric Teaching Hospitals in Baghdad City: Descriptive Study. Karbala journal of pharmaceutical sciences, (8), 110-123.

- Suhara, F., George, J., Chacko, J., Gee, J., \& Dharmarajan, B., (2013): Assessment of knowledge regarding mechanical ventilation among staff nurses working in selected hospital, Mangalore with a view to develop an information pamphlet. International Journal of Recent Scientific Research, 4(9), 1410-1413.

- Veloski, J., Tai, S., Evans, A., \& Nash, D., (2005): Clinical vignette-based surveys: a tool for assessing physician practice variation. American Journal of Medical Quality, 20(3), 151-157. 